\title{
Cognition and Assessment of Tourism Disaster Risk Based on a Tourism Spot of Green Island
}

\author{
Wen-Ching Wang ${ }^{1}$ \& Ching-Jung Wang ${ }^{2}$ \\ ${ }^{1}$ Department of Information Science and Management Systems, National Taitung University, Taiwan \\ ${ }^{2}$ Master, Department of Information Science and Management Systems, National Taitung University, Taiwan \\ Correspondence: Wen-Ching Wang, Department of Information Science and Management Systems, National \\ Taitung University, Taiwan. E-mail: wcwang@nttu.edu.tw
}

Received: November 8, 2018

Accepted: November 23, 2018 Online Published: November 30, 2018

doi:10.5539/enrr.v8n4p32

URL: https://doi.org/10.5539/enrr.v8n4p32

\begin{abstract}
In this study, we examined the risk of offshore travel from the dimensions of tourists and purveyors in the tourism industry. A questionnaire survey was administered for data collection. A factor analysis was performed to determine respondents' perceptions, evaluations and responses, and demands and intentions concerning travel risk, as well as the degree of hazard impact. The analysis results were then used to investigate the similarities and difference of travelers' and tourism purveyors' travel demands. Survey analysis results indicated partial significant differences between travel behaviors and travel risk awareness and travel risk evaluations and responses. In addition, travel risk awareness was partially correlated to travel risk evaluations and responses, travel risk demand and intentions, and degree of hazard impact. Respondents with higher travel risk awareness were more careful in evaluating hazard risk, consequently influencing their tourism and travel behaviors. Applying the analysis results, we addressed traveler-related, operator-related, and environment-related travel risk factors proposed a response strategy for minimizing travel risk, helping parties in the tourism industry cope with hazards and minimizing the risk and losses associated with hazards.
\end{abstract}

Keywords: Factors Analysis, Disaster Risk, Tourism risk perception, Tourism risk assessment travel behavior.

\section{Introduction}

Travel is the journey from a familiar space to an unknown and unfamiliar environment for the purpose of exploration. It exhibits ex-situ and transient attributes and temporarily changes routine and regular lifestyles. Generally, travelers have positive expectations and travel in a rational and pleasant mood (Roehl \& Fesenmaier, 1992). Therefore, they tend to omit unpleasantries subjectively. Moreover, changes in environmental conditions increase the risk of accidents during travel. Risks to include traffic accidents, sanitation, war, safety of environments and facilities, threat of infectious disease, and natural disasters (e.g., typhoons, earthquakes, snowstorms, landslides, and floods) (Fleischer \& Buccola, 2002; Mansfeld \& Pizam, 2006; Anderson,2006; Irvine \& Anderson, 2006; Fuchs \& Reichel, 2006; Cooper, 2005; McKercher \& Chon,2004; Sackett \& Botterill, 2006).

Risk stems from events, and risky events may become dangerous or hazardous (Pearson \& Mitroff, 1993; Faulkner, 2001). Industries are responsible for evaluating the potential risks in the industry (Cox \& Rich, 1964; Cassedy, 1991; Devi \& Raja, 2011; Mitchell \& Vasso, 1997). This is no exception in the travel industry. When tourists travel, they begin to explore the unknown in the space or environment. This is particularly true for first-time visitors to a destination (Pinhey \& Iverson, 1994; Rittichainuwat \& Chakraborty, 2009; Shim, 2004). Each travel process represents a risk journey (Awaritefe, 2004). The primary demand of tourists is to satisfy their travel expectations with the lowest possible risk (Moutinho, 1987). By contrast, tour purveyors aim to satisfy tourists' travel expectations and prevent the occurrence of risky events (Neal et al., 1999). The awareness of travel risks and the ability to identify risk and evaluate the impact or effects of risk on travelers and purveyors are crucial for satisfying the demand of tourists and the supply of purveyors (Kaplan et al., 1974; Fuchs and Reichel, 2011; Ghiselli et al.,1981; Hall et al., 2003; Laws \& Prideaux, 2005; Lepp \& Gibson, 2003; Lepp et al., 2011; Simpson \& Siguaw, 2008) and implementing risk avoidance measures and establishing safe travel environments are key to preventing the occurrence of risky travel events (Levantis \& Gani, 2000). Travel imagery comprises tourists' cognitive and emotional factors (Moutinho, 1987). Tourists' behaviors are 
influenced by their perceptions and evaluations of the destination, and travel imagery influences tourists' selection of recreational destinations. Therefore, tourists take into account not only the environment of the destination but also its imagery when selecting a recreational destination. Birgit (2001) defined "tourist imagery" as tourists' expectations of a destination. It the positive imagery generated by tourists as they gain positive travel experiences. Tourist imagery is a factor influencing tourists' travel considerations, perceptions, and decisions.

Different from general tourist destinations (Barker et al., 2003 et al., Chan et al., 1999; Chen \& Noriega,2003; Chien \& Law, 2003), island destinations feature unique natural landscapes, topographical characteristics, ethnic and cultural factors, distance and isolation qualities. Therefore, these destinations have unique imagery, and they have become travel hot spots. However, these destinations generally have fewer rescue resources and more prone to hazard than general travel destinations due to their fragile and unique environments, economies, societies, and transpiration systems (Chan et al., 1999; Fridgen, 1984; Conant et al., 1988). Hazards that stem from the lack of travel safety and risk knowledge and inadequate response measures not only influence travel safety of tourists but also impact the quality and economic benefits of the travel products offered by tourism purveyors, as well as the overall image of the country. There is always the risk of unsafe or unexpected events during travel that will significantly and negative impact travelers and purveyors. Minimizing travel risk and providing pleasant experiences for both the traveler and operator while promoting tourism and economic development and reducing the degree of hazard impact are crucial issues that should not be undermined.

\section{Tourism Risk and Hazards}

Travel risk comprises many factors. Wang (1995) defined travel risk as “travelers' perceived risk stemming from the travel service terms and conditions of their itineraries and destinations, including risk perception, attention, memory, inference, thinking, expectation, planning, decision, problem-solving, and communication of ideas." The content of travel risk can be categorized into the dimensions of transportation and communication risk, public security risk, accommodation risk, health risk, medical rescue risk, and travel destination risk. Moutinho (1994) categorized travelers' perceived risk into functional risk, physical risk, financial risk, social risk, and psychological risk.

Roehl and Fesenmaier (1995) examined different environments based on travel risk and classified risk into equipment risk, financial risk, physical risk, psychological risk, satisfaction risk, social risk, and time risk.

The travel industry comprises purveyors and travelers. Travel risk varies depending on the risk sensitivity of the two parties, and risk sensitivity is affected by psychological characteristics (Reisinger \& Mavondo,2005; Sönmez a Graefe,1998) personality and motivations (Lepp et al., 2011; Reisinger \& Mavondo, 2005), travel preferences (Lepp \& Gibson, 2003), and travel experiences (Floyd et al., 2003). Therefore, examining the risk perceptions of travelers and purveyors and risk requirements can effectively reduce travel risk.

Travel risk can be predictable, unpredictable, or accidental. The occurrence of risk can be spontaneous or non-spontaneous. The risk of activities in which participants actively or voluntarily participate, such as driving and smoking, is spontaneous and can be predicted. The probability of a risky event occurring can be reduced by reinforcing risk awareness. Natural disasters, fires, or explosions are less predictable or controllable. The occurrences are involuntary and are therefore passive risk. Figure 1 is a representational diagram of the relationship between the causes of risk and travel risk attributes. The figure expresses the probability of the causes of risk and travel risk attributes. Spontaneous risky events are controlled by behavior. They often occur when travelers overlook risk or have inadequate risk awareness. Therefore, the "accidentality" probability of spontaneous risky events is higher than that of "unpredictability" probability. By comparison, non-spontaneous risky events are influenced by the external environment and hazard impact. The events are primarily governed by the environment. Therefore, their "unpredictability" probability is higher than their "accidentality" probability.

The frequency and impact of human-made and natural disasters have risen in recent years (Wang, 2018), consequently increasing the hazard risk of travel activities. In particular, unpredictable natural disasters increase the unpredictability of non-spontaneous events.

Hazard can be defined as "material or situational damage or negative impact on people, environments, or goods" (Burton et al., 1993). Hazards must simultaneously cause risky events and endanger human life or damage good or resources (Mileti, 1999). Travel safety and the occurrence of risky events are influenced by travel structures, travelers, and transaction processes. Risk has many uncertainties and occurs randomly. Therefore, travelers may find the real meaning of travel risk confusing. When assessing the risk of travel activities, travelers generally "rely on person experience," "overestimate the risk of major events that they remember or are easy to remember," "overestimate their ability or luck," "evaluate voluntary or involuntary risk," "evaluate short- and long-term consequences," "evaluate expected probability," "assess the risk limit," and "determine delayed or immediate risk." 


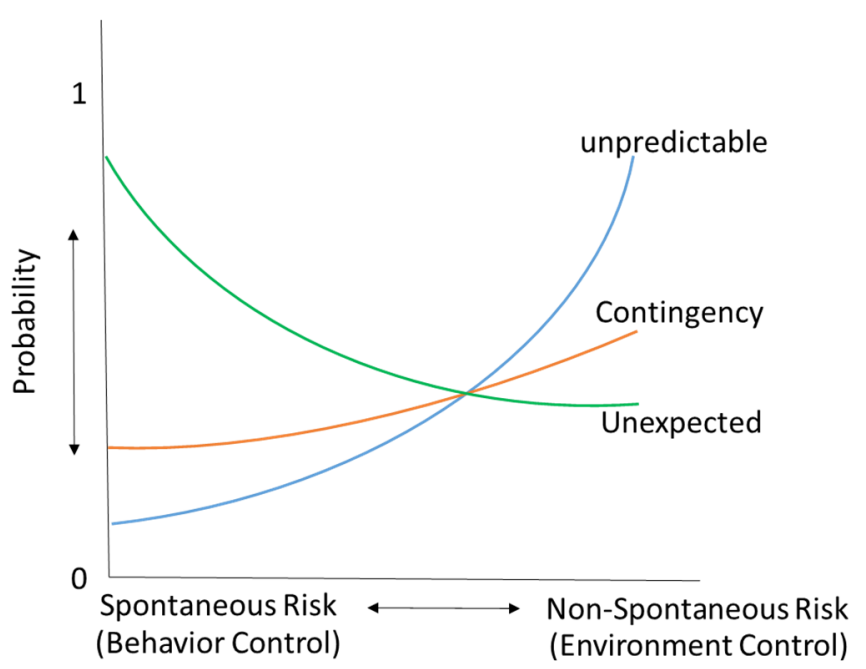

Figure 1. The relationship between the causes of risk and travel risk attributes

\section{Travel Risk Survey and Analysis}

In this study, we examined the hazard awareness and response of offshore travelers. Green Island, a $16.2-\mathrm{km}^{2}$ island off the eastern coast of Taiwan, was selected as the research region. A questionnaire was administered to travelers and purveyors to survey the travel risk awareness, travel risk evaluations and responses, and travel risk demand and intentions of tourists and purveyors in the tourism industry and the degree of hazard impact, and the results were compared to determine the similarities and differences. The primary economic activity on Green Island is tourism, including catering, accommodation, water activities, natural landscapes, human and cultural history, and nature conservation. The island attracts roughly 300,000 travelers annually, who visit the island by ferry or airplane. However, natural disasters, particularly typhoons, frequently threaten the tourism industry on Green Island. These disasters often obstruct transportation, medical resources, and supplies. Typhoons also cause various other environmental hazards that increase the risk to safety.

Tourists are the primary group of travelers to the island. They are also the primary group affected by hazards. We surveyed the hazard awareness and travel behavior of tourists visiting Green Island. Respondents must be over the age of 16 and demonstrate the capacity to complete the questionnaire. A total of 200 valid questionnaires were administered. The questionnaire comprised seven sections, including respondent demographics, attributes of purveyors in the tourism industry, travel behavior, travel risk awareness, travel risk evaluations and responses, travel risk demands and intentions, and degree of hazard impact. A total of 80 valid questionnaires were administered to purveyors. A frequency allocation approach was adopted to analyze the demographic variables of the tourists and tourism purveyors and the travel behaviors of the tourists. Chi-squared tests and single-factor analysis of variance (ANOVA) were conducted on the tourists' demographics and travel behaviors. The Cronbach's $\alpha$ coefficient was adopted to determine the validity and internal consistency of the various constructs, including travel risk awareness, travel risk evaluations and responses, and degree of hazard impact. The coefficients were $0.875,0.886$, and 0.837 , respectively. Outcomes validated the consistency of the constructs and the reliability of the questionnaire used in this study.

\subsection{Travel Risk Factor Analysis}

Twenty factors were analyzed. The Kaiser-Meyer-Olkin (KMO) Test for Sampling Accuracy was adopted to confirm the analytic effects of the data. The KMO value was 0.731 , which indicated moderate sampling accuracy based on the determination criteria proposed by Kaiser (1974). The Bartlett's sphericity value was 5164.210, indicating statistical significance. Principal factor analysis (PCA) was adopted for factor extraction, and varimax rotation was adopted as the rotation method. Using a standard eigenvalue of $>1$, four principal factors were selected. The factors had a collective explanatory power of $77.869 \%$. The name, item, factor loading, eigenvalue, and explained variance of the factor constructs are tabulated in Table 1. 
Table 1. Travel risk factor constructs

\begin{tabular}{|c|c|c|c|}
\hline Factor/Item & Factors loading & Eigenvalues & Explained variance \\
\hline \multicolumn{4}{|l|}{ Factor 1: Environment } \\
\hline Not prone to transportation delays & 0.891 & \multirow{8}{*}{7.488} & \multirow{8}{*}{$37.44 \%$} \\
\hline Hygienic catering & 0.861 & & \\
\hline Safe transportation environment & 0.850 & & \\
\hline Adequate and clear travel and rescue information & 0.762 & & \\
\hline Adequate fire equipment at place of stay & 0.762 & & \\
\hline Not prone to natural disasters & 0.730 & & \\
\hline Safe accommodation environment & 0.708 & & \\
\hline Adequate medical quality and professionalism & 0.624 & & \\
\hline \multicolumn{4}{|l|}{ Factor 2: Safety } \\
\hline The government values travelers' personal safety & 0.933 & \multirow{7}{*}{4.017} & \multirow{7}{*}{$20.09 \%$} \\
\hline Not prone to infectious outbreaks & 0.900 & & \\
\hline $\begin{array}{l}\text { The government and locals are willing to provide assistance } \\
\text { when an accident occurs }\end{array}$ & 0.880 & & \\
\hline Locals are friendly to travelers & 0.795 & & \\
\hline Excellent public security & 0.621 & & \\
\hline Sanitary and hygienic public spaces & 0.595 & & \\
\hline Safe transportation & 0.561 & & \\
\hline \multicolumn{4}{|l|}{ Factor 3: Activity and sights } \\
\hline Professional activity providers & 0.894 & \multirow{4}{*}{2.772} & \multirow{4}{*}{$13.86 \%$} \\
\hline Safe activity facilities & 0.852 & & \\
\hline Safe sight environments & 0.588 & & \\
\hline Clear indication of medical facilities & 0.490 & & \\
\hline \multicolumn{4}{|l|}{ Factor 4. Human-made } \\
\hline Not prone to accidents & 0.860 & 1.297 & $6.48 \%$ \\
\hline
\end{tabular}

\subsection{Travel Risk Awareness Survey and Analysis}

A descriptive analysis method was used to analyze travel risk. The statistical survey results of the travel risk awareness of travelers and industry purveyors are tabulated in Table 2. The results were sorted from highest to lowest. A higher mean value suggested lower risk.

Table 2. Descriptive statistics of tourists' travel risk awareness

\begin{tabular}{|c|c|c|c|c|c|c|c|c|}
\hline \multirow[b]{2}{*}{ Travel risk awareness } & \multicolumn{4}{|c|}{ Tourist } & \multicolumn{4}{|c|}{ Purveyor } \\
\hline & Average & Standard deviation & Variance & Order & Average & $\begin{array}{l}\text { Standard } \\
\text { deviation }\end{array}$ & Variance & Order \\
\hline Not prone to natural disasters & 1.650 & 0.849 & 0.721 & 20 & 2.863 & 1.076 & 1.158 & 17 \\
\hline Not prone to accidents & 1.675 & 0.802 & 0.643 & 18 & 2.613 & 0.961 & 0.924 & 19 \\
\hline Safe transportation & 2.415 & 1.118 & 1.249 & 10 & 2.925 & 1.065 & 1.134 & 14 \\
\hline Safe transportation environment & 2.245 & 0.818 & 0.668 & 12 & 2.788 & 1.027 & 1.056 & 18 \\
\hline Not prone to transportation delays & 1.845 & 0.988 & 0.976 & 17 & 3.138 & 0.951 & 0.905 & 11 \\
\hline Safe accommodation environment & 2.580 & 1.067 & 1.139 & 9 & 3.138 & 0.990 & 0.981 & 10 \\
\hline Adequate fire equipment at place of stay & 2.275 & 0.868 & 0.753 & 11 & 2.938 & 0.985 & 0.971 & 13 \\
\hline Excellent public security & 3.160 & 0.899 & 0.808 & 6 & 3.525 & 0.993 & 0.987 & 2 \\
\hline The government values travelers' personal safety & 4.035 & 0.979 & 0.959 & 1 & 3.100 & 1.086 & 1.180 & 12 \\
\hline Locals are friendly to travelers & 3.980 & 0.795 & 0.633 & 2 & 3.650 & 1.045 & 1.091 & 1 \\
\hline $\begin{array}{l}\text { The government and locals are willing to provide } \\
\text { assistance when an accident occurs }\end{array}$ & 3.800 & 0.702 & 0.492 & 3 & 3.213 & 0.951 & 0.904 & 6 \\
\hline Hygienic catering & 2.180 & 0.837 & 0.701 & 14 & 3.263 & 0.896 & 0.804 & 4 \\
\hline Not prone to infectious outbreaks & 3.705 & 0.929 & 0.862 & 4 & 3.175 & 0.839 & 0.703 & 8 \\
\hline Sanitary and hygienic public spaces & 3.015 & 1.005 & 1.010 & 8 & 3.325 & 0.854 & 0.728 & 3 \\
\hline Adequate medical quality and professionalism & 1.670 & 0.758 & 0.574 & 19 & 2.363 & 1.094 & 1.196 & 20 \\
\hline Clear indication of medical facilities & 2.180 & 0.912 & 0.832 & 16 & 2.900 & 0.894 & 0.800 & 16 \\
\hline Activity facilities are safe & 3.140 & 0.962 & 0.925 & 7 & 3.188 & 0.943 & 0.888 & 7 \\
\hline Professional activity providers & 3.300 & 0.868 & 0.754 & 5 & 3.250 & 0.987 & 0.975 & 5 \\
\hline Adequate and clear travel and rescue information & 2.245 & 0.854 & 0.729 & 13 & 2.925 & 0.854 & 0.728 & 15 \\
\hline Safe sight environments & 2.180 & 0.831 & 0.691 & 15 & 3.163 & 0.906 & 0.821 & 9 \\
\hline
\end{tabular}




\section{(1) Tourists}

According to Table 2, travelers were highly aware of the social and public security constructs. Most of the tourists on Green Island believed that the government valued their safety, the locals were friendly to them, and the government and locals were willing to provide assistance when an accident occurs. Therefore, the respondents believed that public security was excellent. They also believed that Green Island was not prone to infectious outbreaks, activity providers were professional, and activity equipment was safe.

In terms of the travel environment, the tourists perceived Green Island to be prone to natural disasters, and delays in transportation were frequent. They also believed the risk of human-related accidents was high. Most of the tourist believed that the quality and professionalism of the medical institution were inadequate, and they were unfamiliar with the location of the medical institution.

Overall, the mean values of the "not prone to natural disasters" and "not prone to human-related accidents" items were 1.65 and 1.675 , indicating that the respondents disagreed that Green Island was not prone to natural disasters and human-related accidents. In terms of the "transportation accident" construct, the mean values for "safe transportation," "safe transportation environment," and "not prone to transportation delays" were 2.415 , 2.245 , and 1.845, respectively. Most of the tourists disagreed that transportation and transportation environment on Green Island was safe. In terms of the "accommodation safety" construct, the mean values for "safe accommodation environment" and "adequate fire equipment at place of stay" were 2.275 and 2.58 , suggesting that the respondents believed that the fire equipment at their place of stay was inadequate and that their place of stay was unsafe. In terms of the "social and public security" construct, the mean values for the "excellent public security," "the government values travelers' personal safety," and "locals are friendly to travelers' items were $3.160,4.035$, and 3.980, respectively, indicating that the respondents acknowledged social and public security. In terms of the "overall sanitation" construct, the mean values for the "not prone to infectious outbreaks" and "sanitary and hygienic public spaces" items were 3.705 and 3.015, indicating that the respondents believed that Green Island was not prone to infectious outbreaks and that the public spaces were sanitary and hygienic. The mean value for the "hygienic catering" item was 2.180 , suggesting that the respondents disagreed that the restaurants on Green Island were hygienic. In terms of the "medical resources" construct, the mean values for "adequate medical quality and professionalism" and "clear indication of medical facilities" items were 1.670 and 2.180 , indicating that the respondents disapproved that the medical quality and professionalism were adequate and that there were clear indications of medical facilities. In terms of the "travel sight" construction, the mean values for the "adequate and clear travel and rescue information" and "safe sight environments" items were 2.245 and 2.180, suggesting that the respondents disagreed with these items. The respondents had a higher acknowledgment for the "safe activity facilities" and "professional activity providers" items, which had mean values of 3.14 and 3.30 .

\section{(2) Industry purveyors}

According to Table 2, the purveyors believed that the locals were friendly to tourists, Green Island had excellent public security, public spaces were sanitary and hygienic, restaurant environments were hygienic, and activity providers were professional. However, the purveyors believed that the quality and professionalism of the medical institution was inadequate, Green Island was prone to natural disasters, and the transportation environment was unsafe.

In terms of the various constructions, the mean values for the "not prone to natural disasters" and "not prone to human-related accidents" items were 2.863 and 2.613 , suggesting the purveyors perceived that these items were high-risk items.

In terms of the "transportation accident" construct, the mean value for the "not prone to transportation delays" item was 3.138. However, the mean value for the "safe transportation environment" item was 2.788, suggesting the purveyors perceived that this item was a high-risk item. In terms of the "accommodation safety" construct, the mean values for the "safe accommodation environment" item was 3.138. However, the mean value for the "adequate fire equipment at place of stay" item was 2.938 , suggesting the purveyors perceived that this item was a high-risk item. In terms of the "social and public security" construct, the mean value for the "locals are friendly to travelers" item was 3.65. However, the mean value for the "the government values travelers' personal safety" item was 3.100, suggesting the purveyors perceived that this item was a high-risk item. In terms of the "overall sanitation" construct, the mean value for "sanitary and hygienic public spaces" was 3.325. However, the mean value for the "not prone to infectious breakouts" item was 3.175, suggesting the purveyors perceived that this item was a high-risk item. In terms of the "medical resources" construct, the mean values for the "adequate medical quality and professionalism" and "clear indication of medical facilities" items were 2.363 and 2.900, 
suggesting that the purveyors disapproved that the quality and professionalism of the medical institution was adequate and medical facilities were clearly indicated. In terms of the "travel sites" construct, the mean value for the "adequate and clear travel and rescue information" item was 2.925, suggesting that the purveyors disapproved that the travel and rescue information was adequate and clear. However, the mean value for the "professional activity providers" item was 3.250, suggesting that the purveyors acknowledged the professionalism of the activity providers.

\subsection{Travel Risk Evaluations and Responses}

\section{(1) Factor Analysis of Travel Risk Evaluations and Responses}

Fifteen factors were analyzed. The KMO Test for Sampling Accuracy was adopted to confirm the analytic effects of the data. The KMO value was 0.911 , which indicated moderate sampling accuracy based on the determination criteria proposed by Kaiser (1974). The Bartlett's sphericity value was 6179.283 , indicating statistical significance. PCA was adopted for factor extraction, and varimax rotation was adopted as the rotation method. Using a standard eigenvalue of $>1$, two principal factors were selected. The factors had a collective explanatory power of $88.195 \%$. The name, item, factor loading, eigenvalue, and explained variance of the factor constructs are tabulated in Table 3 .

Table 3. Factors and constructs of travel risk evaluations and responses

\begin{tabular}{|c|c|c|c|}
\hline Factor/Item & Factors loading & Eigenvalues & Explained variance \\
\hline \multicolumn{4}{|l|}{ Factor 1: Environment } \\
\hline $\begin{array}{l}\text { Cancellation of trip on account that the government does not } \\
\text { value travelers' safety }\end{array}$ & 0.903 & \multirow{11}{*}{12.210} & \multirow{11}{*}{$81.402 \%$} \\
\hline Cancellation of trip on account of a breach in public security & 0.895 & & \\
\hline Cancellation of trip on account of infectious outbreak & 0.888 & & \\
\hline $\begin{array}{l}\text { Cancellation of trip on account of reports of a transportation } \\
\text { accident }\end{array}$ & 0.867 & & \\
\hline Cancellation of trip on account of a natural disaster & 0.814 & & \\
\hline $\begin{array}{l}\text { Cancellation of trip on account of the sight being in a danger } \\
\text { zone }\end{array}$ & 0.740 & & \\
\hline Cancellation of trip on account of inconvenient transportation & 0.729 & & \\
\hline $\begin{array}{l}\text { Cancellation of trip on account of inadequate medical } \\
\text { resources }\end{array}$ & 0.708 & & \\
\hline $\begin{array}{l}\text { Cancellation of trip on account of unregistered } \\
\text { accommodation }\end{array}$ & 0.708 & & \\
\hline $\begin{array}{l}\text { Cancellation of trip on account of an unsafe accommodation } \\
\text { environment }\end{array}$ & 0.697 & & \\
\hline Cancellation of trip on account of unhygienic catering & 0.683 & & \\
\hline \multicolumn{4}{|l|}{ Factor 2: Safety } \\
\hline $\begin{array}{l}\text { Cancellation of trip on account of inadequate rescue } \\
\text { equipment or professional guides }\end{array}$ & 0.897 & \multirow{4}{*}{1.019} & \multirow{4}{*}{$6.792 \%$} \\
\hline $\begin{array}{l}\text { Cancellation of trip on account of inadequate travel or rescue } \\
\text { information }\end{array}$ & 0.872 & & \\
\hline $\begin{array}{l}\text { Cancellation of trip on account of reports of a human-related } \\
\text { accidents }\end{array}$ & 0.806 & & \\
\hline Cancellation of trip on account of changes in the weather & 0.794 & & \\
\hline
\end{tabular}

(2) Analysis of the tourists' travel risk evaluations and responses

A descriptive statistics approach was adopted to analyze tourists' travel risk evaluations and responses. Table 4 shows that $60 \%$ of the tourists had previously no considered the "natural disasters" factor. Subsequently, $30 \%$ of the tourists previously canceled their trip due to "hazardous weather," while $34 \%$ of the respondents had previously considered this factors, suggesting that weather was the foremost factor of evaluation for tourists. Most of the tourists had not previously considered the "human-related accidents," "transportation accident," "social and public security," "overall sanitation," and "medical resources" factors. For "accommodation safety," $23.5 \%$ of the tourists considered the accommodation environment, suggesting that tourists valued the safety of accommodation environments. For "travel sights," tourists considered the professionalism of activity providers $(38 \%)$ and travel information (42.5\%), suggesting that the valued the safety of travel activities and travel sights. 
Table 4. Allocation table of tourists' travel risk evaluations and responses (\%)

\begin{tabular}{|c|c|c|c|c|}
\hline Item & Yes & $\begin{array}{l}\text { Did not } \\
\text { cancel }\end{array}$ & No & $\begin{array}{l}\text { Yes, but it does not influence my } \\
\text { intentions }\end{array}$ \\
\hline $\begin{array}{l}\text { Would you cancel your trip on account of a natural } \\
\text { disasters }\end{array}$ & 0 & 24.5 & 60 & 15.5 \\
\hline $\begin{array}{l}\text { Would you cancel your trip on account of changes in the } \\
\text { weather }\end{array}$ & 30 & 26 & 10 & 34 \\
\hline $\begin{array}{l}\text { Would you cancel your trip on account of reports of a } \\
\text { human-related accident }\end{array}$ & 3.5 & 8 & 62.5 & 26 \\
\hline $\begin{array}{l}\text { Would you cancel your trip on account of reports of a } \\
\text { transportation accident }\end{array}$ & 1 & 27 & 64.5 & 7.5 \\
\hline $\begin{array}{l}\text { Would you cancel your trip on account of inconvenient } \\
\text { transportation }\end{array}$ & 0 & 22.5 & 58 & 19.5 \\
\hline $\begin{array}{l}\text { Would you cancel your trip on account of unregistered } \\
\text { accommodation }\end{array}$ & 1 & 37.5 & 51.5 & 10 \\
\hline $\begin{array}{l}\text { Would you cancel your trip on account of an unsafe } \\
\text { accommodation environment }\end{array}$ & 0 & 27 & 49.5 & 23.5 \\
\hline $\begin{array}{l}\text { Would you cancel your trip on account of a breach in } \\
\text { public security? }\end{array}$ & 0.5 & 24.5 & 68 & 7 \\
\hline $\begin{array}{l}\text { Would you cancel your trip on the account that the } \\
\text { government does not value travelers' safety? }\end{array}$ & 0 & 26 & 66.5 & 7.5 \\
\hline $\begin{array}{l}\text { Would you cancel your trip on account of an infectious } \\
\text { outbreak? }\end{array}$ & 0 & 23.5 & 69.5 & 7 \\
\hline $\begin{array}{l}\text { Would you cancel your trip on account of unhygienic } \\
\text { catering }\end{array}$ & 0 & 33.5 & 47 & 19.5 \\
\hline $\begin{array}{l}\text { Would you cancel your trip on account of inadequate } \\
\text { medical resources }\end{array}$ & 0 & 35.5 & 49 & 15.5 \\
\hline $\begin{array}{l}\text { Would you cancel your trip on account of the sight being } \\
\text { in a danger zone }\end{array}$ & 0 & 33 & 51.5 & 15.5 \\
\hline $\begin{array}{l}\text { Would you cancel your trip on account of inadequate } \\
\text { rescue equipment or professional guides }\end{array}$ & 0 & 9.5 & 52.5 & 38 \\
\hline $\begin{array}{l}\text { Would you cancel your trip on account of inadequate } \\
\text { travel or rescue information }\end{array}$ & 1.5 & 9.5 & 46.5 & 42.5 \\
\hline
\end{tabular}

(3) Analysis of purveyors' hazard risk prevention awareness

The survey results of the purveyors' hazard risk prevention awareness are tabulated in Table 5. The purveyors believed that leaving Green Island (3.113) and providing hazard prevention knowledge and training (3.65) did not help hazard prevention. They expressed that storing materials (3.9) and securing windows and roofs (3.875) were more helpful.

Table 5. Descriptive statistics of purveyors' hazard risk prevention awareness

\begin{tabular}{lcccc}
\hline \multicolumn{1}{c}{ Hazard risk prevention } & Mean & $\begin{array}{c}\text { Standard } \\
\text { deviation }\end{array}$ & Variance & Order \\
\hline Staff education of hazard prevention knowledge and training & 3.650 & 0.982 & 0.965 & 2 \\
First ensure the safety of tourists and staff & 3.775 & 0.914 & 0.835 & 6 \\
Purchase insurance & 3.825 & 0.854 & 0.728 & 7 \\
Hazard response plan & 3.738 & 0.951 & 0.905 & 4 \\
Provide rescue information & 3.713 & 0.970 & 0.942 & 3 \\
Have a first-aid kit ready & 3.763 & 1.009 & 1.019 & 5 \\
Have auxiliary power or a power generator ready & 3.875 & 0.891 & 0.794 & 8 \\
Temporarily leave Green Island & 3.113 & 0.981 & 0.962 & 1 \\
Store food, water, and a flashlight & 3.875 & 0.832 & 0.693 & 9 \\
Secure windows, roofs, and signs & 3.900 & 0.976 & 0.952 & 10 \\
\hline
\end{tabular}




\subsection{Correlations between Travel Risk Awareness, Evaluation, Demand, and Degree of Hazard Impact}

(1) Correlation analysis of tourists' travel risk awareness and travel risk evaluations and responses

The correlation between tourists' travel risk awareness and travel risk evaluations and responses are tabulated in Table 6. "Natural disaster" awareness had moderately negative correlations with the "natural disasters" and "medical resources" factors of travel risk evaluations and responses, suggesting that tourists' awareness of natural disasters influenced their evaluations of natural disasters and medical resources and that natural disasters reduced their travel willingness. "Transportation accidents" awareness had a moderately negative correlation with the "travel sights" factor of travel risk evaluations and responses. The tourists evaluated the safety of the transportation environment of the travel sight. Poor transportation affected their travel willingness. "Accommodation safety" awareness had moderately negative correlation with the "accommodation safety" and "travel sights" factors of travel risk evaluations and responses, suggesting that the tourists considered the hazardous impact of the accommodation environment. "Social and public security" awareness had moderately negative correlations with the "accommodation safety" and "travel sights" factors of travel risk evaluations and responses, suggesting that the tourists considered the public security conditions of the accommodation environment and travel sight. "Overall sanitation" awareness had a moderately negative correlation with the "accommodation safety" factor of travel risk evaluations and responses, suggesting that the tourists considered the cleanliness of the accommodation environments. "Medial resource" awareness had moderately negative correlations with the "transportation accidents" and "travel sights" factors of travel risk evaluations and responses, suggesting that the tourists considered the adequacy of medical resources during a transportation accident or at a travel sight. "Travel sight" awareness had a moderately negative correlation with the "travel sights" factor of travel risk evaluations and responses, suggesting that the tourists considered the safety of the travel sight and the adequacy of rescue information.

Table 6. Correlation analysis of Green Island tourists' travel risk awareness and travel risk evaluations and responses

\begin{tabular}{|c|c|c|c|c|c|c|c|c|}
\hline \multirow[b]{2}{*}{ Travel risk evaluations and response } & \multicolumn{8}{|c|}{ Travel risk awareness } \\
\hline & $\mathrm{e}^{\text {Natural disaste }}$ & $\begin{array}{l}\text { Iuman-relatec } \\
\text { accidents }\end{array}$ & $\begin{array}{c}\text { Transportatio } \\
\text { accidents }\end{array}$ & $\begin{array}{c}\text { commodatio } \\
\text { safety }\end{array}$ & $\begin{array}{l}\text { Social and } \\
\text { public } \\
\text { security }\end{array}$ & $\begin{array}{c}\text { Overall } \\
\text { sanitation }\end{array}$ & $\begin{array}{l}\text { Medical } \\
\text { resources }\end{array}$ & $\begin{array}{l}\text { Travel } \\
\text { sights }\end{array}$ \\
\hline Natural disasters & $-.346(* *)$ & 0.008 & 0.071 & $-.414(* *)$ & 0.005 & $-.192(* *)$ & $-.336(* *)$ & -0.035 \\
\hline Human-related accidents & $-.308(* *)$ & 0.044 & $-.318(* *)$ & $-.279(* *)$ & $-.254(* *)$ & $-.279(* *)$ & $-.276(* *)$ & $-.280(* *)$ \\
\hline Transportation accidents & $-.273(* *)$ & 0.043 & $-.233(* *)$ & $-.597(* *)$ & $-.316(* *)$ & $-.182(* *)$ & $-.502(* *)$ & $-.213(* *)$ \\
\hline Accommodation safety & $-.301(* *)$ & 0.011 & $-.297(* *)$ & $-.653(* *)$ & $-.323(* *)$ & $-.520(* *)$ & $-.246(* *)$ & $-.256(* *)$ \\
\hline Social and public security & $-.259(* *)$ & 0.057 & $-.112(*)$ & $-.462(* *)$ & $-.195(* *)$ & $-.360(* *)$ & $-.367(* *)$ & $-.155(* *)$ \\
\hline Overall sanitation & $-.251(* *)$ & 0.068 & $-.104(*)$ & $-.556(* *)$ & $-.189(* *)$ & $-.392(* *)$ & $-.444(* *)$ & $-.135(* *)$ \\
\hline Medical resources & $-.310(* *)$ & 0.027 & $-.357(* *)$ & $-.389(* *)$ & $-.174(*)$ & $-.354(* *)$ & $-.375(* *)$ & $-.323(* *)$ \\
\hline Travel sights & $-.304(* *)$ & 0.041 & $-.506(* *)$ & $-.632(* *)$ & $-.392(* *)$ & $-.457(* *)$ & $-.628(* *)$ & $-.403(* *)$ \\
\hline
\end{tabular}

Note: * represents $\mathrm{P} \leqq 0.05, * *$ represents $\mathrm{P} \leqq 0.01$, and $* * *$ represents $\mathrm{P} \leqq 0.001$

(2) Correlation analysis of Green Island tourists' travel risk evaluations and responses and degree of hazard impact

The correlations between tourists' travel risk evaluations and responses and the degree of hazard impact are tabulated in Table 7. Results indicated that "natural disasters," "dietary hygiene," and "medical resources" failed to correlate with the various factors of travel risk evaluations and responses, "destinations," "transportation accidents." "accommodation safety," "social and public security," and "travel sights" had moderate correlations with the various factors of travel risk evaluations and responses, suggesting that when tourists' take into account hazards, "destinations," "transportation accidents." "accommodation safety," "social and public security," and "travel sights" only have a small impact on their decisions. 
Table 7. Analysis of Green Island tourists' travel risk evaluations and responses and degree of hazard impact

\begin{tabular}{|c|c|c|c|c|c|c|c|c|}
\hline $\begin{array}{l}\text { Travel risk evaluations and } \\
\text { responses }\end{array}$ & $\begin{array}{l}\text { Natural } \\
\text { disasters } \\
\end{array}$ & $\begin{array}{c}\text { Human-related } \\
\text { accidents } \\
\end{array}$ & $\begin{array}{c}\text { Transportation } \\
\text { accidents } \\
\end{array}$ & $\begin{array}{c}\text { Accommodation } \\
\text { safety } \\
\end{array}$ & $\begin{array}{c}\text { Social and public } \\
\text { security }\end{array}$ & $\begin{array}{c}\text { Overall } \\
\text { sanitation }\end{array}$ & $\begin{array}{l}\text { Medical } \\
\text { resources }\end{array}$ & $\begin{array}{l}\text { Travel } \\
\text { sights }\end{array}$ \\
\hline Natural disasters & -0.097 & -0.119 & -0.068 & -0.023 & -0.101 & -0.104 & -0.060 & -0.047 \\
\hline Time & 0.120 & 0.129 & $.147(*)$ & 0.135 & 0.130 & $.159(*)$ & 0.114 & 0.125 \\
\hline Destinations & $-.408(* *)$ & $-.393(* *)$ & $-.380(* *)$ & $-.279(* *)$ & $-.431(* *)$ & $-.405(* *)$ & $-.314(* *)$ & $-.320(* *)$ \\
\hline Transportation accidents & $-.341(* *)$ & $-.365(* *)$ & $-.321(* *)$ & $-.229(* *)$ & $-.358(* *)$ & $-.337(* *)$ & $-.270(* *)$ & $-.281(* *)$ \\
\hline Accommodation safety & $-.429(* *)$ & $-.419(* *)$ & $-.432(* *)$ & $-.321(* *)$ & $-.479(* *)$ & $-.451(* *)$ & $-.357(* *)$ & $-.349(* *)$ \\
\hline Social and public security & $-.423(* *)$ & $-.391(* *)$ & $-.387(* *)$ & $-.297(* *)$ & $-.464(* *)$ & $-.431(* *)$ & $-.329(* *)$ & $-.339(* *)$ \\
\hline Dietary hygiene & 0.005 & 0.035 & 0.027 & 0.027 & 0.012 & 0.042 & 0.021 & 0.017 \\
\hline Medical resources & 0.111 & 0.100 & $.155\left(^{*}\right)$ & 0.128 & $.145\left(^{*}\right)$ & 0.136 & 0.129 & 0.123 \\
\hline Travel sights and activities & $-.336(* *)$ & $-.301(* *)$ & $-.295(* *)$ & $-.205(* *)$ & $-.324(* *)$ & $-.341(* *)$ & $-.251(* *)$ & $-.261(* *)$ \\
\hline Life property & $-.182(* *)$ & -0.126 & $-.147\left(^{*}\right)$ & -0.085 & $-.183(* *)$ & $-.162\left(^{*}\right)$ & $-.139\left(^{*}\right)$ & -0.130 \\
\hline
\end{tabular}

Note: * represents $\mathrm{P} \leqq 0.05,{ }^{* *}$ represents $\mathrm{P} \leqq 0.01$, and $* * *$ represents $\mathrm{P} \leqq 0.001$.

\subsection{Difference Analysis of Tourist and Purveyors}

(1) Analysis of travel risk

Figure 2 shows that the social and public security and overall sanitation constructs of the tourists and purveyors were fairly similar. Both groups had a fairly low consideration for the two constructs. The tourists had a higher regard for natural disasters, human-related accident, and medical resources than the purveyor.

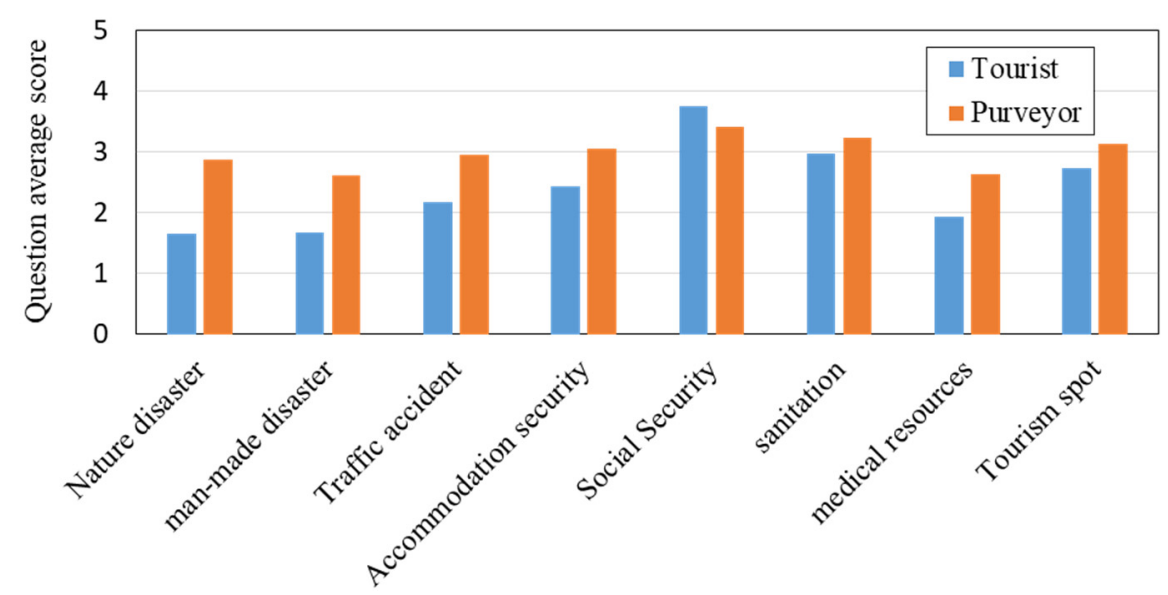

Figure 2. Comparison of tourism risk cognition between tourist and purveyor

(2) Analysis of hazard demands and intentions

Figure 3 shows that the primary hazard demands for tourist and purveyor were immediate rescue and adequate medical resources. These results indicated that both tourists and purveyors demanded rapid response, professional rescue and adequate medical resources. Different from the purveyors, the tourist expected a favorable communication environment and to immediately leave Green Island when a hazard occurs. Purveyors expected a safe environment and sufficient hazard prevention equipment and resources. A number of purveyors also expected government intervention, while the tourists did not expect government support. 


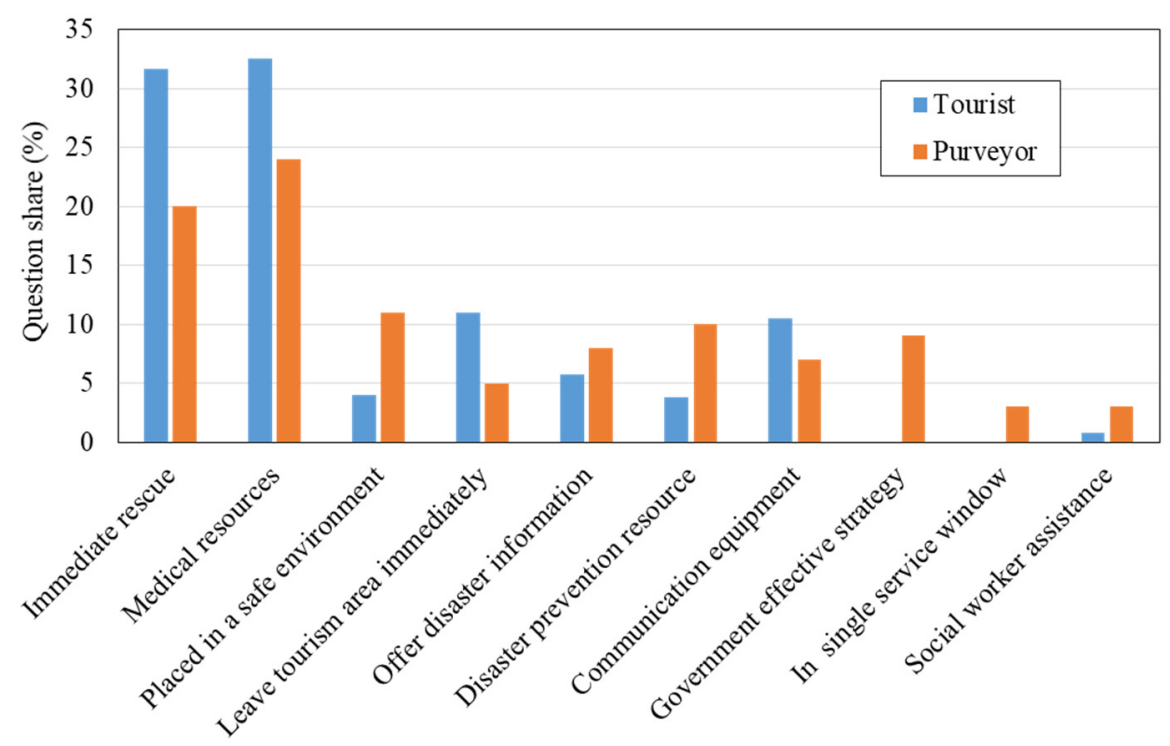

Figure 3. Comparison of disaster demand intention between tourist and purveyor

(3) Analysis of the impact of hazard risk

Figure 4 shows that the tourists and purveyors considered medical resources and transportation accidents to have a significant impact on hazard risk. The impact of social and public security and life property on hazard risk was less evident. The impact of natural disasters, time, and accommodation safety perceived by the tourists was higher than that of the purveyors. These results reflected the similarities of and differences between travelers' perceptions of self-preservation and purveyors' perceptions of risky events. The greatest discrepancy was factors concerning the medical system. Purveyors are responsible for ensuring the safety of and protecting travelers. Both groups urgently require medical resources during a medical emergency. Therefore, the two groups had similar considerations concerning medical resources. In terms of natural disasters, time, and accommodation, travelers generally have safety requirements and time pressure. Purveyors are less concerned with these factors. Therefore, differences were observed between the two groups concerning these factors.

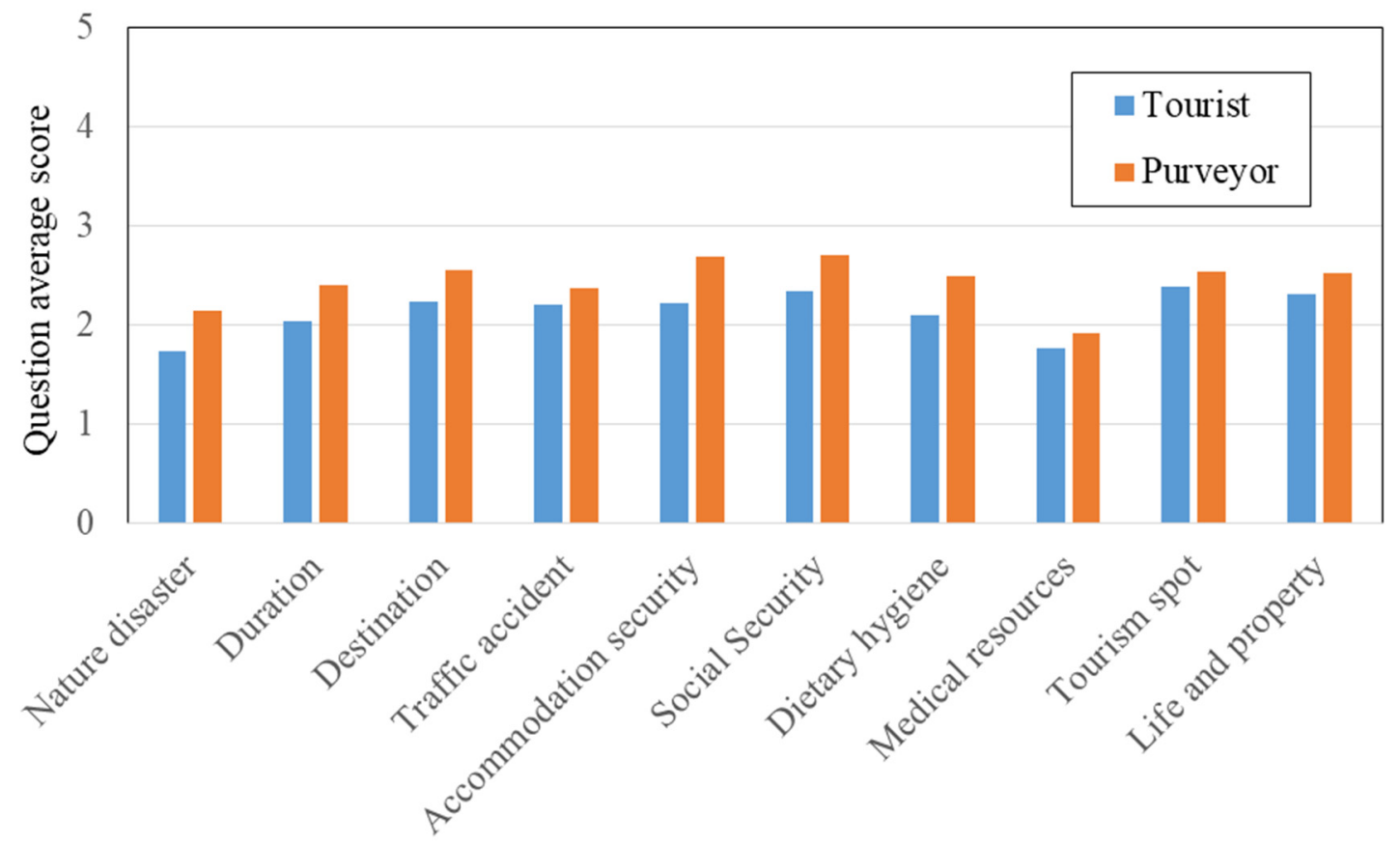

Figure 4. Comparison of the impact between tourist and purveyor 


\section{Hypothetical Test}

In order to explore the risk of tourism. There are 6 hypotheses, (H1) Travel risk awareness is significantly correlated to travel risk evaluations and responses, hazard demands and intentions, and degree of hazard impact; $(\mathrm{H} 2)$ Travel risk evaluations and responses are significantly correlated to hazard demands and intentions and degree of disaster impact (H3) Hazard demands and intentions are significantly correlated to degree of hazard impact (H4) Relevant similarities of and differences between tourists' travel risk awareness and purveyors' perceptions of tourists' travel risk awareness (H5) Relevant similarities of and differences between tourists' travel risk demand and intentions and purveyors' perceptions of tourists' travel risk demands and intentions (H6) Relevant similarities of and differences between tourists' degree of hazard impact and purveyors' perceptions of tourists' degree of hazard impact, have been identify before the questionnaire was put forward. Based on the questionnaire survey and analysis results, the 06 hypotheses were tested as shown in the table 8 .

Table 8. Hypothesis test outcomes and explanations

\begin{tabular}{|c|c|}
\hline Hypot & Test outcomes and explanation \\
\hline $\begin{array}{l}\text { H1: Travel risk awareness is significantly } \\
\text { correlated to travel risk evaluations and } \\
\text { responses, hazard demands and intentions, } \\
\text { and degree of hazard impact. }\end{array}$ & $\begin{array}{l}\text { Supported: Travel risk awareness had significant correlations with travel risk evaluations and } \\
\text { responses, hazard demands and intentions, and degree of hazard impact }\end{array}$ \\
\hline $\begin{array}{l}\text { H2: Travel risk evaluations and responses } \\
\text { are significantly correlated to hazard } \\
\text { demands and intentions and degree of } \\
\text { disaster impact. }\end{array}$ & $\begin{array}{l}\text { Travel risk evaluations and responses had no significant correlations with hazard demands } \\
\text { and intention, suggesting that tourists' pre-travel risk evaluations are unrelated to the } \\
\text { information required during a hazard. Travel risk evaluations had significant correlations with } \\
\text { degree of hazard impact, suggesting that the degree of hazard impact decreases concurrently } \\
\text { with an increase in pre-travel evaluations. }\end{array}$ \\
\hline $\begin{array}{l}\text { rd demands and intentions are } \\
\text { tly correlated to degree of hazard }\end{array}$ & $\begin{array}{l}\text { ed: Hazard demands and intentions had no significant correlations with degree of } \\
\text { impact, indicating that the information required during a hazard did not influence } \\
\text { risk perceptions. }\end{array}$ \\
\hline $\begin{array}{l}\text { H4: Relevant similarities of and differences } \\
\text { between tourists' travel risk awareness and } \\
\text { purveyors' perceptions of tourists' travel } \\
\text { risk awareness. }\end{array}$ & $\begin{array}{l}\text { Similarities: Perceptions of social and public security and overall sanitation were fairly } \\
\text { similar. Both groups perceived these factors to be high-risk factors. } \\
\text { Differences: Tourists' awareness of natural disasters, human-related accidents, and medical } \\
\text { resources were higher than that of the purveyors. }\end{array}$ \\
\hline $\begin{array}{l}\text { H5: Relevant similarities of and differences } \\
\text { between tourists' travel risk demand and } \\
\text { intentions and purveyors' perceptions of } \\
\text { tourists' travel risk demands and intentions }\end{array}$ & $\begin{array}{l}\text { Differences: The tourists expected a favorable communication environment and to leave } \\
\text { Green Island immediately when a hazard occurs. The purveyors expected a safe environment } \\
\text { and adequate hazard prevention resources and equipment. }\end{array}$ \\
\hline $\begin{array}{l}\text { H6: Relevant similarities of and differences } \\
\text { between tourists' degree of hazard impact } \\
\text { and purveyors' perceptions of tourists' } \\
\text { degree of hazard impact }\end{array}$ & $\begin{array}{l}\text { Similarities: Both groups believed that medical resources and transportation accidents have a } \\
\text { strong impact on hazards. } \\
\text { Differences: The tourists' perceptions of the impact of natural disasters, time, and } \\
\text { accommodation safety were higher than those of the purveyors. }\end{array}$ \\
\hline
\end{tabular}

\section{Conclusion}

Using samples collected on Green Island off the east coast of Taiwan, we invested tourists' travel risk awareness, travel risk evaluations and responses, hazard demands, and degree of hazard impact, as well as Green Island tourism purveyors' travel risk awareness, travel risk evaluations and responses, hazard demands, and degree of hazard impact. In addition, the two parties were cross-analyzed. The analysis results serve as a reference for travelers and tourism purveyors when evaluating travel risk and formulating response strategies. The key research results are as follows:

\section{(1) Natural disasters and travel behaviors}

The tourists and purveyors deemed the "natural disasters" factor to be a high-risk factor. The potential damages and losses caused by natural disasters are highly uncertain. Tourists often consider the weather before making travel arrangements. Poor weather conditions, such as heavy rain or uncertainty of a typhoon, impact tourists' willingness. However, natural disasters cannot be accurately predicted. Relevant departments can improve their disaster prevention systems and disaster prevention knowledge. For the purveyors, they believed that disaster prevention knowledge or disaster prevention education and training did not produce tangible benefits. Nonetheless, disaster prevention knowledge must be improved to formulate effective countermeasures and restoration plans. 


\section{(2) Transportation environment and travel behaviors}

Tourists are unable to control the transportation environment. They are only able to self-evaluate relevant risks. The tourists and purveyors had different views concerning the safety of transportation environments. After a hazard, the tourists hoped to safely leave Green Island and valued the demands and rights of the purveyors and residents. To mitigate risk, transportation infrastructure should be improved, and an emergency response mechanism or protocol should be implemented. In addition, adequate transportation safety education and training should be provided to relevant staff. Relevant transportation accident response measures should be planned and implemented, road inspection and maintenance should be reinforced, and road conditions should be closely monitored. Local purveyors should also inform tourists about dangerous areas and remind them to travel safely.

\section{(3) Accommodation safety and travel behaviors}

The analysis results on accommodation safety indicated that tourists did not agree that adequate fire equipment was available that the place of stay. Although the majority of tourists did not consider accommodation safety, the factor influenced their future recommendations and re-visitation willingness. Therefore, authorities should assist bed and breakfast purveyors in installing security systems and conduct inspections to ensure that the system meets regulatory standards. In addition, authorities should focus on improving the legal registration of bed and breakfasts to ensure accommodation safety. The length of stay of travelers is relatively short. Unlike residents, tourists are less attentive to the prevention of accidents and hazards. We recommend that tourists include a flashlight and clean plastic bags in their luggage so that they have the tools necessary for escape during a fire or outage. Purveyors must abide by local laws and regulations and ensure that they properly maintain fire equipment and inform tourists of the locations of the fire escapes and equipment.

\section{(4) Overall sanitation and travel behaviors}

The tourists disapproved of food and beverage hygiene. The cleanliness of the catering environment should be improved to enhance tourists' willingness to visit and recommend the environment to their friends, family members, and other tourists. Authorities should encourage purveyors to reinforce hygiene management and strengthen supervisory systems, thereby providing a clean catering environment to tourists, avoid the occurrence of food poisoning, and ensure tourists' health.

\section{(5) Medical resources and travel behavior}

Transportation in offshore locations is generally inconvenient, and people are sparkly dispersed. Therefore, these locations are less likely to attract doctors, leading to an inadequacy in medical resources. The tourists perceived medical resources to be a high-risk factor. They expected to immediately receive rescue services and adequate medical attention in the occurrence of a hazard. Therefore, authorities should plan and establish an emergency medical response system, add medical equipment and improve supporting measures, and provide relevant training to strengthen the emergency rescue performance of front-line medical professionals, thereby achieving favorable response times and preventing the spread of disease. In addition, remote medical systems should also be improved, such as providing ad hoc medial information over the telephone or Internet or by directly speaking to a medical professional. Aerial rescue should also be reinforced to improve the response time of helicopter medics.

(6) Social and public security and travel behaviors

The tourists and purveyors did not perceive offshore social and public security to be a high-risk factor. Nonetheless, this factors can still be improved. For example, a travel security service network can be planned and established to provide timely services to tourists, prevent theft, and maintain order. Alternatively, a travel security service hotline can be implemented, and professional training for travel security services can be provided to create or improve various long-term mechanics, such as major travel safety information communication, travel safety warning, response and handling of unexpected events, and periodic evaluation of travel safety trends, thereby enhancing travel safety and tourism image.

\section{(7) Travel sights and travel behaviors}

Risk analysis results indicated that the tourists and purveyors approved of the professionalism of the managers at the travel destinations. However, they felt that the travel and rescue information was inadequate, which severely impacted the tourists' travel willingness. Relevant parties should periodically update the travel information, recommended trips, post-hazard disclosures on their websites, provide detailed rescue and warning information, highlight hazard areas, locations, shelters, and donation stations on online maps, establish safety instructions at travel sights, and provide emergency contact information. In addition, relevant parties should encourage activity providers to participate in professional training or staff vacations to gain new experiences and information and provide tourists with more professional knowledge. 


\section{Acknowledge}

The authors are thankful for supported by the Ministry of Science and Technology of Taiwan under Grants MOST 107-2119-M-143-001.

\section{Reference}

Anderson, B.A. (2006). Crisis management in the Australian tourism industry: Preparedness, personnel, and postscript. Tourism Management, 27(6), 1290-1297. https://doi.org/10.1016/j.tourman.2005.06.007.

Awaritefe, O. D. (2004). Destination image differences between prospective and actual tourists in Nigeria. Journal of Vacation Marketing, 10(3), 264-281.

Barker, M., Page, S., \& Meyer, D. (2003). Urban visitor perceptions of safety during a special event. Journal of Travel Research, 41(4), 355-361.

Birgit, L. (2001). Image Segmentation: The Case of a Tourism Destination. Journal of services marketing, 15(1), 49-66.

Burton, I., Kates, R.W., \& White, G.F. (1993). The Environmental as Hazard (2nd ed.). New York: Guilford.

Cassedy, K., (1991). Crisis management planning in the travel and tourism industry. The Pacific Asia Travel Association.

Chan, Y., Hui, T. \& Yuen, E. (1999). Modeling the impact of sudden environmental changes on visitor arrival forecasts: The case of the Gulf War. Journal of Travel Research, 37(4), 391-394.

Chen, R., \& Noriega, P. (2003). The impacts of terrorism: perceptions of faculty and students on safety and security in tourism. Journal of Travel and Tourism Marketing, 15(2/3), 81-98.

Chien, G.C.L., \& Law, R. (2003). The impact of the severe acute respiratory syndrome on hotels: A case study of Hong Kong. International Journal of Hospitality Management, 22(3), 327-332.

Conant, J., Clark, T., Burnett, J. \& Zank, G. (1988). Terrorism and travel: Managing the unmanageable. Journal of Travel Research, 26(4), 16-20.

Cooper, M. (2005). Japanese tourism and the SARS epidemic off 2003. Journal of Travel and Tourism Marketing, 19(2), 117-131.

Cox, D.F., \& Rich, S.J. (1964). Perceived risk and consumer decisions making: The case of telephone shopping. Journal of Marketing Research, 4(1), 32-39.

Devi, P.M., \& Raja, S.B. (2011). Importance and the zone of tolerance of passengers' expectations of Indian railway passengers services by applying RAILQUAL. Asian Journal of Management Research, 1(2), 387-401.

Faulkner, B. (2001). Towards a framework for tourism disaster management. Tourism Management, 22, 135-147.

Fleischer, A., \& Buccola, S. (2002). War, terror, and the tourism market in Israel. Applied Economics, 34(11), 1335-1343.

Floyd, M.F., Gibson, H., Pennington-Gray, L., \& Thapa, B. (2003). The effect of risk perceptions on intentions to travel in the aftermath of September 11, 2001. Journal of Travel \& Tourism Marketing, 15(2), 19-38.

Fridgen, J.D. (1984). Environmental psychology and tourism. Annals of Tourism Research, 11(1), 19-39.

Fuchs, G., \& Reichel, A. (2011). An exploratory inquiry into destination risk perceptions and risk reduction strategies of the first time vs. repeat visitors to a highly volatile destination. Tourism Management, 32(2), 266-276.

Fuchs, G., \& Reichel, A. (2006). Tourist destination risk perception: The case of Israel. Journal of Hospitality and Leisure Marketing, 14(2), 83-108.

Ghiselli, E.E., Campbell, J.P., \& Zedeck, S. (1981). Measurement theory for the behavioral sciences. San Francisco: Freeman.

Hall, C., Timothy, D., \& Duval, D. (2003).Towards a new understanding: Security and tourism. Journal of Travel and Tourism Marketing, 15(2/3), 1-18.

Irvine, W., \& Anderson, A.R. (2006). The effect of disaster on peripheral tourism places and the disaffection of prospective visitors. In Y. Mansfeld, \& A. Pizam (Eds.), Tourism, security \& safety: From theory to practice (pp. 169-186). Oxford, UK: Butterworth-Heinemann. 
Kaiser, H. F., (1974). An index of factorial simplicity. Psychometrika, 39(1), 31-36.

Kaplan, L.B., Szybillo, G.J., \& Jacoby, J. (1974). Components of perceived risk in product purchase: A cross-validation. Journal of Applied Psychology, 59(3), 287-291.

Laws, E., \& Prideaux, B. (2005). Crisis management: A suggested typology. Journal of Travel and Tourism Marketing, 19(2/3), 1-8.

Lepp, A., \& Gibson, H. (2003). Tourist roles, perceived risk and international tourism. Annals of Tourism Research, 30(3), 606-624.

Lepp, A., Gibson, H., \& Lane, C. (2011). Image and perceived risk: A study of Uganda and its official tourism website. Tourism Management, 32(3), 675-684.

Levantis, T., \& Gani, A. (2000). Tourism demand and the nuisance of crime. International Journal of Social Economics, 27(7-10), 959-967.

Mansfeld, Y., \& Pizam, A. (2006). Tourism, security and safety: from the theory to practice, in chapter 1: Toward a Theory of Tourism Security (pp. 1-27). UK: Butterworth-Heinemann.

McKercher, B., \& Chon, K. (2004). The over-reaction to SARS and the collapse of Asian tourism. Annals of Tourism Research, 31(3), 716-719.

Mileti, D.S. (1999). Disasters by Design. Washington D.C.: Joseph Henry Press.

Mitchell, V.W., \& Vasso, V. (1997). Perceived risk and risk reductions in holiday purchase: A cross-cultural and gender analysis. Journal of Euromarketing, 6(3), 47-97.

Moutinho, L. (1987). Consumer behavior in tourism. European Journal of Marketing, 21(10), 5-25.

Neal, J.D., Sirgy, M.J., \& Uysal, M. (1999). The role of satisfaction with leisure travel/ tourism services and experience in satisfaction with leisure life and overall life. Journal of Business Research, 44(3), 153-163.

Pearson, C.M., \& Mitroff, I.I.(1993). From crisis prone to crisis prepared: A framework for crisis management. Academy of Management Executive, 7(1), 48-59.

Pinhey, T.K., \& Iverson, T.J. (1994). Safety concerns of Japanese visitors to Guam. Journal of Travel \& Tourism Marketing, 3(2), 87-94.

Reisinger, Y., \& Mavondo, F. (2005). Travel anxiety and intentions to travel internationally: Implications of travel risk perception. Journal of Travel Research, 43(3), 212-225.

Rittichainuwat, B.N., \& Chakraborty, G. (2009). Perceived travel risks regarding terrorism and disease: The case of Thailand. Tourism Management, 30(3), 410-418.

Roehl, W.S., \& Fesenmaier, D.R. (1992). Risk perceptions and pleasure travel: An exploratory analysis. Journal of Travel Research, 30(4), 17-26.

Sackett, H., \& Botterill, D. (2006). Perceptions of international travel risk: An exploratory study of the influence of proximity to terrorist attack. e-Review of Tourism Research, 4(2), 44-49.

Shim, J.M. (2004). The evolution of leisure studies in North America and South Korea: A study of cultural consensus (Doctoral Dissertation). The Pennsylvania State University, PA.

Simpson, P.M., \& Siguaw, J. A. (2008). Perceived travel risks: The traveler perspective and manageability. International Journal of Tourism Research, 10(4), 315-327.

Sönmez, S.F., \& Graefe, A.R. (1998). Influence of terrorism risk on foreign tourism decisions. Annals of Tourism Research, 25(1), 122-144.

Wang K.C. (1998). The Establishment of Evaluation Model for Travelling Risk-Application of Fuzzy Multiple Criteria Decision Making (Doctoral Dissertation). Chinese, Culture University, Taiwan.

Wang, W.C. (2018). Setting up evaluate indicators for slope control engineering based on spatial clustering analysis. Natural Hazards, 93, 921-939.

\section{Copyrights}

Copyright for this article is retained by the author(s), with first publication rights granted to the journal.

This is an open-access article distributed under the terms and conditions of the Creative Commons Attribution license (http://creativecommons.org/licenses/by/4.0/). 